\title{
Cancer mortality in a Chinese population surrounding a multi-metal sulphide mine in Guangdong province: an ecologic study
}

\author{
Mao Wang ${ }^{1}$, Hong Song ${ }^{1 *}$, Wei-Qing Chen², Ciyong Lu², Qianshen Hu', Zefang Ren², Yan Yang ${ }^{1}$, Yanjun Xu', \\ Aiming Zhong ${ }^{4}$ and Wenhua Ling $^{5^{*}}$
}

\begin{abstract}
Background: The Dabaoshan mine in the southeast of Guangdong Province, China, is at high risk of multi-metal pollutant discharge into a local river (Hengshihe) and the surrounding area. Following approximately 30 years of exposure to these metals, little is known regarding the subsequent health effects and risks for the local residents. In our present study, we have estimated the relationships between long-term environmental exposure to multiple heavy metals and the risk of cancer mortality in a Chinese population in the vicinity of Dabaoshan.

Methods: An ecologic study was performed. Between 2000-2007, a total population of 194,131 lived in the nine agricultural villages that surround the Hengshihe area. Heavy metals concentrations were determined in local environmental samples (water and crops) and whole blood taken from 1152 local residents of both a highexposure area (HEA) and a low-exposure area (LEA). We calculated the rate ratio and standardized mortality ratios based on age- and gender-specific cancer mortality rates for the different reference populations (based on district, county and province). Simple, multiple linear and ridge regression models were used to evaluate the associations between exposure to multiple heavy metals and cancer mortality in the nine villages, after adjustment for age and sex.
\end{abstract}

Results: The geometric mean blood levels of cadmium and lead were measured at $24.10 \mu \mathrm{g} / \mathrm{L}$ and $38.91 \mu \mathrm{g} / \mathrm{dL}$ for subjects $(n=563)$ in the HEA and $1.87 \mu \mathrm{g} / \mathrm{L}$ and $4.46 \mu \mathrm{g} / \mathrm{dL}$ for subjects $(n=589)$ from the LEA, respectively $(P<$ 0.001). The rate of mortality from all cancers in the HEA was substantially elevated in comparison with the corresponding mortality rate in the LEA for men (rate ratio $=2.13 ; 95 \%$ confidence intervals $=1.63-2.77$ ) and women (2.83; 1.91 - 4.19); rates were also significantly elevated compared with the rate when compared to the entire Wengyuan County area, or the provincial reference population. In addition, mortality rates were significantly increased for stomach, lung and esophageal cancer in the HEA in comparison with the corresponding rates in the LEA, in Wengyuan County and the provincial reference population for men, women and both combined. Further analysis showed that there were significantly positive correlations between exposure to cadmium and lead and the risk of all-cancers and stomach cancer mortality among women and both sexes, whilst zinc exposure showed no association with the risk of site-specific cancer mortality in the nine villages evaluated.

Conclusions: The findings of this study reveal probable associations between long-term environmental exposure to both cadmium and lead and an increased risk of mortality from all cancer, as well as from stomach, esophageal and lung-cancers.

\footnotetext{
* Correspondence: songhong@mail.sysu.edu.cn; lingwh@mail.sysu.edu.cn 'Department of Preventive Medicine, School of Public Health, Sun Yat-Sen University, Guangzhou, China

${ }^{5}$ Department of Nutrition, School of Public Health, Sun Yat-Sen University, Guangzhou 510080, China

Full list of author information is available at the end of the article
} 


\section{Background}

The Dabaoshan mine, built in 1958, is located to the southeast of Shaoguan City, Guangdong Province, China. Since the 1970s, the mine has been in full-scale operation as a large-scale and integrative quarrying mine. This facility plays an important role for both the non-ferrous metal materials and steel industries in southern China. The mine itself contains multi-metal sulphide mineral deposits, including limonite in the superior part of ore body with a reservoir of 20 million tons, and copper-sulphide lying in the inferior part of the ore body with a reservoir also of 20 million tons [1]. Mineral separation at the mine has been incomplete, and most of the lean ore has been discarded and become gradually weathered. During processing, including leaching, ore dressing, and washing, substantial quantities of waste water are discharged directly into the environment. Both the discarded ore and waste water from the mine constitute severe environmental pollutants for the surrounding and downstream areas.

Previous surveys $[2,3]$ have shown that the $\mathrm{pH}$ of the wastewater from Dabaoshan is 2.15 , and that the cadmium $(\mathrm{Cd})$, lead $(\mathrm{Pb})$ and zinc $(\mathrm{Zn})$ concentrations in the irrigation water of nearby crop regions were 16-, 5.0- and 3-fold higher, respectively, than the government approved standards (The Standards for Irrigation Water Quality, GB 5084-1992). Zhou et al. [1] have further found that the $\mathrm{pH}$ of the soils in the fields irrigated with this polluted water was approximately 4.0 , and that the lead and cadmium concentrations in the soil are 44-fold and 12-fold higher, respectively, than the government standards (The Environmental Quality Standard for Soils, GB 15618-1995). One study in 2005 has also reported that the concentrations of heavy metals in soils in the Hengshihe River region exceed the national standards (China), particularly for $\mathrm{Zn}$, copper $(\mathrm{Cu})$ and $\mathrm{Cd}$ [4]. The definition of a "heavy metal" includes a specific gravity of more than 5 or a density greater than $4.5 \mathrm{~g} /$ $\mathrm{cm}^{3}$, and the 45 established heavy metals include $\mathrm{Cu}$, $\mathrm{Zn}, \mathrm{Pb}, \mathrm{Cd}$ and manganese [5]. A previous study by Cai et al. [6] has reported that the levels of $\mathrm{Pb}, \mathrm{Zn}, \mathrm{Cu}$ and $\mathrm{Cd}$ in sediment from the Hengshihe river, which functions as a mine drainage afflux, are as high as 1841.02, $2326.28,1522.61$ and $10.33 \mathrm{mg} / \mathrm{kg}$ respectively. These levels are far higher than the maximum concentrations recommended for soil, in particular the $\mathrm{Cu}$ and $\mathrm{Cd}$ concentrations which were found to be 14-fold and 4-fold higher, respectively, than the government standards (GB 15618-1995) [6]. The surface-layer soils in the coastal areas near to the Hengshihe river also showed large aggregations of $\mathrm{Cd}, \mathrm{Pb}, \mathrm{Zn}$ and $\mathrm{Cu}$.

Cadmium and cadmium compounds have been established as carcinogens, mainly from epidemiological data for occupational exposure [7], whereas lead is classified as a possible carcinogen in humans [8,9]. However, many previous epidemiologic studies of the relationships between $\mathrm{Cd}$ or $\mathrm{Pb}$ exposure and cancer have only been undertaken in occupational settings $[10,11]$. There is strong evidence for a positive association between occupational exposure to $\mathrm{Cd}$ and lung cancer risk $[10,12]$. However, the association of $\mathrm{Cd}$ with other potential target organs, such as the stomach, liver and prostate, remains equivocal [13-15]. Moreover, although both of these heavy metals are ubiquitous environmental pollutants, there is a current lack of evidence for human cancer causation by oral exposure to $\mathrm{Cd}$ or $\mathrm{Pb}[15,16]$. In addition, due to the antioxidant role of zinc, it is conceivable that there may be a protective effect of a high zinc status against cancer development $[10,17]$.

In addition to $\mathrm{Cd}, \mathrm{Pb}$ and $\mathrm{Zn}, \mathrm{Cu}$ is another environmental pollutant from Dabaoshan, which contains substantial copper-sulphide mineral deposits. $\mathrm{Cu}$ is an essential nutrient and a redox-active transition metal that may initiate oxidative damage to lipids, proteins, DNA and contribute to neurodegenerative disorders, especially at high concentration [18]. High levels of $\mathrm{Cu}$ can also induce growth proliferation and cancer by damaging DNA via toxic free hydroxyl radicals [19]. Chronic $\mathrm{Cu}$ toxicity is rare and primarily affects the liver [20]. On the other hand, $\mathrm{Cu}$ is essential for optimal antioxidant defense, and a $\mathrm{Cu}$ deficiency may increase cellular susceptibility to oxidative damage [21]. High intakes of ascorbic acid and zinc may reduce $\mathrm{Cu}$ toxicity by reducing $\mathrm{Cu}$ intake [22,23]. To our knowledge however, there have been few studies of the associations between environmental exposure to multiple heavy metals over a period as long as 30 years and human cancer mortality.

Because the Hengshihe river is the main drainage pathway for effluent from the Dabaoshan mine, it has been polluted since the 1970s. The river thus delivers significant quantities of heavy metals to numerous villages in its region. After about 30 years of exposure to these metals, some local residents in the Hengshihe area have begun to acquire upper gastrointestinal diseases, for example, both oesophageal and stomach cancer are of a priori interest. To date however, there has been no study of the detrimental effects of long-term environmental exposure to multiple heavy metals on the local general population other than our previous report that heavy metal exposures are associated with an increased risk of behavioral problems in schoolaged children [24].

In our current study, we aimed to determine the heavy metal levels in the water, supply, field crops and residents' blood in the area around Dabaoshan mine and evaluate the relationships between these exposures and the human cancer mortality rates. 


\section{Methods}

\section{Study area and population}

The present study was conducted in a high-exposure area [HEA] downstream of the Hengshihe river in Shaoguan city, including the villages of Shangba (I), Xiaozhen (II) and Dongfang (III), and a low-exposure area [LEA] which was selected as a reference area about 35 kilometers from the river and includes the villages of Zhongxin (IV), Shaping (V), Shuikou (VI), Mashan (VII), Fengshan (VIII), and Madun (IX) (Figure 1). The Hengshihe river is the source of drinking and irrigation water for Shangba and Xiaozhen, and ground water, which may be contaminated by Hengshihe, is the source of drinking and irrigation water for Dongfang village. In the LEA, the sources of drinking and irrigation water are the Huangzhuping and Guizhu reservoirs. The nine villages under study belong to areas of Wengyuan County and most (>95\%) of the residents are moderately educated farmers with an average annual income per capita of less than US\$556.00. There is no heavy industry in this region and little air pollution from automobiles. The two reference populations comprised individuals who lived in Wengyuan County and the rural areas of Guangdong province (RAGDP) from 2004-2005 [25].

\section{Water, soil and crop analysis}

Water, soil and crop samples were taken from both the HEA and LEA using standard methods as previously described [24]. One and two water source samples, respectively, were taken from the HEA and LEA. Irrigation water, well, soil, rice, and avena nuda samples were also taken from each village. The levels of $\mathrm{Cd}, \mathrm{Pb}, \mathrm{Cu}$ and $\mathrm{Zn}$ in these environmental samples were determined by standard methods as previously described [24].

\section{Blood analysis}

A cross-sectional study was performed in July 2006. The samples were selected using simple random sampling. In each village, we identified a random population sample stratified by sex and age (18-39 years vs 40-59 years $v s$ $60-74$ years $v s \geq 75$ years), with the aim of recruiting equal numbers from each group. The nine village municipalities gave listings of all inhabitants sorted by address. Households, defined as those who lived at the same address, were used as the sampling unit. We numbered the households consecutively, and generated a random-number list using the SPSS random function. Households with a number matching the list were invited to participate and any household member older than 18 years was eligible. Individuals were not included if the quota for age-sex stratum had been met. Among a total of 1180 eligible participants, 1152 (97.6\%) completed the survey. The study population thus comprised
563 residents from the HEA and 589 from the LEA. At baseline, we used a validated questionnaire that asked about lifestyle, consumption of local food including rice, water and various crops, past and current place of residence, possible exposures to toxic substances, smoking and drinking habits, and previous medical history. Whole blood samples were collected from all 1152 participants by well-trained nurses and shipped at $-20^{\circ} \mathrm{C}$ to our laboratory at the School of Public Health, Sun YatSen University in an appropriate manner to avoid any external contamination.

Microwave-assisted acid digestion was conducted using previously described methods for whole blood $[24,26]$. The accuracy of the results was evaluated using a cattle serum (freeze-dried) reference sample (Chinese Certificated Reference Materials GBW(E) 090006, Beijing, China). Atomic absorption measurements were made using a polarized Zeeman atomic absorption spectrometer (Hitachi-5000, Japan). The detection limits were set at $0.8 \mu \mathrm{g} / \mathrm{L}$ for $\mathrm{Pb}, 0.06 \mu \mathrm{g} / \mathrm{L}$ for $\mathrm{Cd}, 0.5 \mu \mathrm{g} / \mathrm{L}$ for $\mathrm{Cu}$ and $0.005 \mathrm{mg} / \mathrm{L}$ for $\mathrm{Zn}$. The precision of the measurements was in the range of $\pm 3-5 \%$.

\section{Retrospective ecological mortality studies}

A third retrospective cause of death investigation of residents living in the Guangdong province from 20042005 was conducted in August 2006 [25]. The investigation samples were selected using a proportional allocation stratified cluster random sampling design. According to the stratification methodology of the National Bureau of Statistics of China, cities and counties/districts belonging to Guangdong province are classified as either big cities (population $>500,000$ ), middle and small cities (population $<50,0000$ ), I rural areas and II rural areas [27]. Using the data from the third National Census, rural areas are classified as richer, rich, poor and poorer according to health status (mortality, infant mortality and birth rate), population structure (number of people younger than 14 and older than 65 in the population and the population density), and economic conditions (the per-capita gross output values from the industry and agriculture sectors, activity rate for secondary industries, and the illiteracy rate). The richer and rich areas are classed as I rural whereas poor and the poorer areas are classed as II rural [27].

The definition of proportional allocation is the proportion of each of these four stratifications within the sample cohort that is coincident with that of Guangdong province according to the fifth National Census in China in 2000 (1.3: 1.8: 7.2: 1) [28]. Concurrently, we performed the same cause of death survey for the period 2000-2007 in the nine villages included in our present report. The residents living in Wengyuan County and in the RAGDP from 2004 to 2005 from the third 


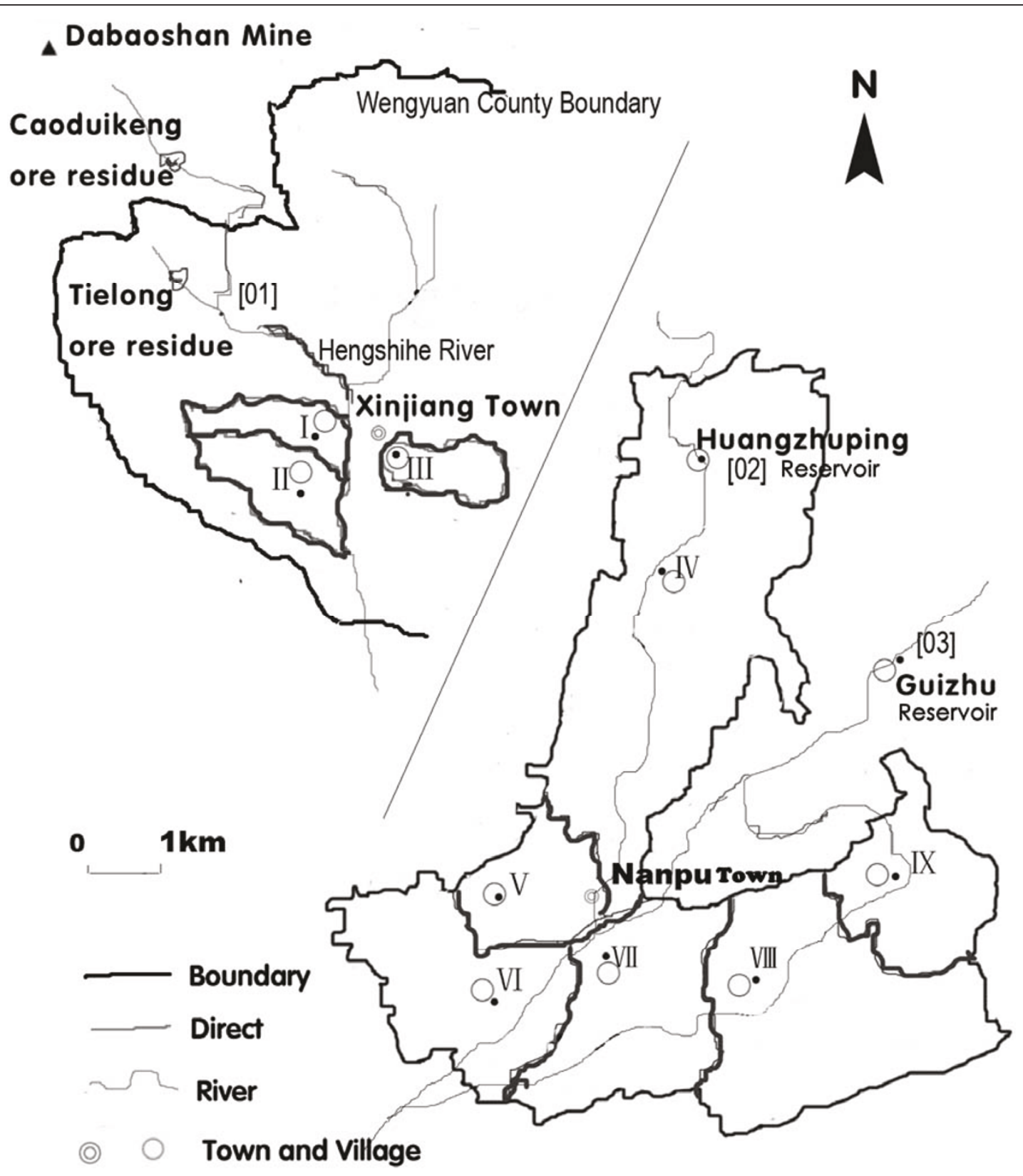

[01]. Sampling of water source and others

Figure 1 Geographic map of the region encompassing the Dabaoshan Mine ( $\Delta$ ), the surrounding area, the HEA [Shangba Village (I), Xiaozhen Village (II) and Dongfang Village (III)] and LEA [Zhongxin Village (IV), Shaping Village (V), Shuikou Village (VI), Fengshan Village (VII), Mashan Village (VIII) and Madun Village (IX)].

retrospective investigation were selected as our two reference populations (Figure 2). Considering the different environmental and lifestyle factors underlying cancer, the residents living in the town where the county government was located were excluded from the RAGDP population. All reported deaths in the above- studied population had death certificates archived by local police departments, $89 \%$ of which were confirmed by a county physician [29]. Moreover, all death certificates were verified through door-to-door surveys or by the well-trained investigators at the local examination centers. To control for quality of the analyses, strict 


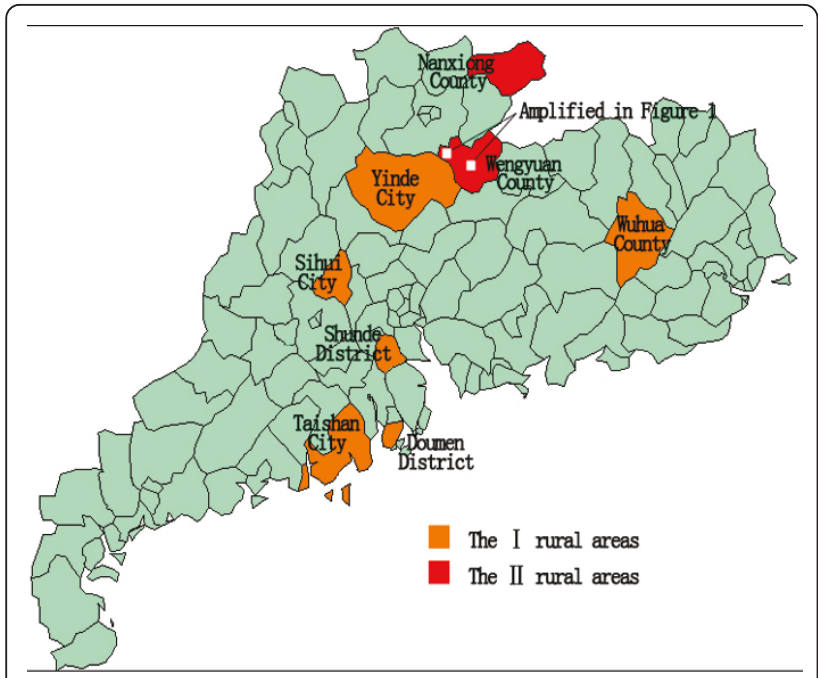

Figure 2 Geographic map of the third retrospective investigation of causes of death in the RAGDP of China spanning 2004-2005 conducted by the provincial health department and the School of Public Health of Sun Yat-Sen University (Notes: These areas were classified as type I or type II rural areas according to the socioeconomic status (SES). Type I rural areas had a high SES and included Shunde district, Sihui city, Wuhua county, Doumen district, Taishan city and Yingde city. The type II rural areas had a low SES and included Wengyuan county and Nanxiong county.

measures were used for every component of the investigation, including the design stage, on-the-spot investigations, data collection, sorting and analysis [30]. Twelve trained nosologists had previously validated the coding used on the death certificates [31]. The International Classification of Diseases, tenth revision (ICD-10) [32] was used to identify deaths that were due to a malignant neoplasm (codes C00-C97) [33].

\section{Statistical analysis}

The heavy metal concentrations in various sample types from the HEA were compared with counterpart samples from the LEA and with the current government standards in China. Log transformations were used to adjust the blood metal levels and age-adjusted cancer mortality rates for skewness. Blood metal levels were reported as the geometric mean and standard deviation (SD). We compared mean values using the standardized normal $z$ test, and frequencies using chisquare test. Data from the Fifth National Census in China in 2000 for gender and 5-year age groups were used to calculate both the standardized mortality rate and expected number of cancer deaths in each of nine studied villages, the HEA, the LEA, Wengyuan County and the RAGDP population.

For comparison of the average cancer mortality rates in the HEA with those in the LEA, a binomial statistical distribution was assumed for both data sets when performing chi-square tests to calculate association probabilities for the ratio of rates (RR). This was also assumed when using 95\% confidence intervals and 2sided hypothesis test probabilities with the PEPI Compare 2 program using the option "Rates with no.-of-individuals denominators" [34,35] for the comparison of the rates in the HEA to the averaged rates in Wengyuan County and the RAGDP population from 2004-2005, respectively (the middle of 2000-2007 survey period). A Poisson statistical distribution was assumed in calculating the exact mid-P 95\% CIs and 2-sided hypothesis test probabilities for 70 or fewer deaths, and approximate Fisher CIs and probabilities for more than 70 deaths, using the PEPI Describe computer program with the option "Compute SMR or indirectly standardized rate" [34,35].

At the population level, simple, multiple linear and ridge regression models were used to further analyze correlations between blood heavy metal concentrations and age-adjusted mortality from selected site-specific cancer in the nine villages evaluated. If the blood heavy metal concentrations were found to be highly correlated with each other, then collinearity was considered as it is well known that it can affect the accuracy of the results [36]. Hence, a ridge regression was applied to address the instability of parameter estimates in the presence of collinearity, adjusting for gender and age. Ridge regression models were developed based on the adjusted $\mathrm{R}^{2}$ selection method. Ridge regression stabilizes model parameter estimates by multiplying a contant (i.e., Ridge $k$ ) to the elements of the correlation matrix, displacing it from singularity and statistically compensating for the effects of multicollinearity. Ridge Trace and variance inflation factor (VIF) plots were employed to determine the most efficient Ridge $k$ used to bias least-square estimators of model parameters (i.e., coefficients), because increasing values of the Ridge $k$ also superficially inflate the mean square error of the model, which has negative consequence on model diagnostics. The objective was to determine the lowest Ridge $k$ that reasonably stabilized the coefficient and their VIFs, which reflect the variance of a coefficient relative to its variance if all the predictor variables in the model were uncorrelated. All analyses were carried out separately for men and women. All statistical analyses were performed using SPSS software, version 13.0 (SPSS Inc., Chicago, IL). All significance tests were two-sided using 0.05 as the level of statistical significance.

\section{Ethical approval}

This study received approval from the Sun Yat-Sen University, School of Public Health Ethics Committee. All participants provided signed informed consent. 


\section{Results}

\section{Environmental pollution}

The heavy metal concentrations in environmental samples from the HEA were found to be far higher than those from the LEA and the accepted government standards (Table 1). In the HEA, the waste water was acidic $(\mathrm{pH}=3.35)$ and contained concentrations of cadmium and zinc that reached $7.09 \times 10^{-3} \mathrm{mg} / \mathrm{L}$ and $13.7 \mathrm{mg} / \mathrm{L}$, respectively, which far exceeded the government standards of $5.00 \times 10^{-3} \mathrm{mg} / \mathrm{L}$ and $1.00 \mathrm{mg} / \mathrm{L}$, respectively. A significantly higher content of both $\mathrm{Cd}$ and $\mathrm{Zn}$ than allowable by government standards were also found in the irrigation water and wells in Shangba village, which is the closest population center to the Dabaoshan mine. In the village of Dongfang, the $\mathrm{Pb}$ concentration in the avena nuda, soil and rice samples was higher than the corresponding levels in the LEA. The highest concentrations of $\mathrm{Cd}$ and $\mathrm{Pb}$ were measured at $0.47 \mathrm{mg} / \mathrm{kg}$ (Shangba), and $830 \mathrm{mg} / \mathrm{kg}$ (Shangba), respectively, in rice; and $0.13 \mathrm{mg} / \mathrm{kg}$ (Shangba), and $1690 \mathrm{mg} / \mathrm{kg}$ (Xiaozhen), respectively, in avena nuda.

\section{Social-demographic characteristics and heavy metal levels} in blood

A cross-sectional study revealed that there were similar socioeconomic status (SES), dietary and geographic

Table 1 Heavy Metal Concentrations in Environmental Samples near a Multi-metals Sulphide Mine in Guangdong, China

\begin{tabular}{|c|c|c|c|c|c|}
\hline & \multicolumn{3}{|c|}{ High-Exposure Area } & \multirow{2}{*}{$\begin{array}{l}\text { Low-Exposure Area } \\
\text { Six villages }\end{array}$} & \multirow[t]{2}{*}{$\mathrm{GS}^{\mathrm{a}}$} \\
\hline & Shangba & Xiaozhen & Dongfang & & \\
\hline $\mathrm{N}$ (excluding water source) & 1 & 1 & 1 & 6 & \\
\hline \multicolumn{6}{|l|}{$\mathrm{pH}$} \\
\hline Water source & \multicolumn{3}{|c|}{3.35 (Wastewater) $^{\text {b }}$} & 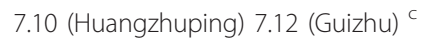 & $6.0-9.0$ \\
\hline Irrigation water & 4.92 & 7.75 & 7.76 & $7.02-7.35$ & $5.50-8.50$ \\
\hline Well water & 4.77 & 7.06 & 6.88 & $7.04-7.56$ & $6.5-8.5$ \\
\hline \multicolumn{6}{|l|}{ Cadmium } \\
\hline Water source $\left(\mathrm{mg} / \mathrm{L}, \times 10^{-3}\right)$ & \multicolumn{3}{|c|}{7.09 (Wastewater) $^{\text {b }}$} & 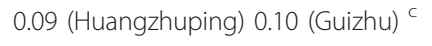 & 5 \\
\hline Irrigation water $\left(\mathrm{mg} / \mathrm{L}, \times 10^{-3}\right)$ & 8.31 & 4.25 & 0.66 & $<0.001$ & 5 \\
\hline Well water $\left(\mathrm{mg} / \mathrm{L}, \times 10^{-3}\right)$ & 8.88 & 0.13 & 0.07 & $<0.001$ & 5 \\
\hline Soil (mg/kg) & 0.528 & 0.422 & 0.043 & $0.032-0.18$ & 0.30 \\
\hline Rice (mg/kg) & 0.47 & 0.36 & 0.02 & $0.006-0.075$ & 0.20 \\
\hline Avena nula (mg/kg) & 0.13 & 0.06 & 0.01 & $0.004-0.060$ & 0.20 \\
\hline \multicolumn{6}{|l|}{ Lead } \\
\hline Water source (mg/L) & \multicolumn{3}{|c|}{0.043 (Waste water) $^{b}$} & 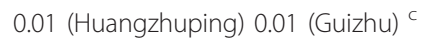 & 0.010 \\
\hline Irrigation water (mg/L) & 0.045 & 0.035 & 0.013 & $<0.01$ & 0.200 \\
\hline Well water (mg/L) & 0.012 & 0.017 & 0.016 & $<0.01-0.02$ & 0.01 \\
\hline Soil (mg/kg) & 600 & 770 & 68 & $7.13-19.93$ & 300 \\
\hline Rice $(\mathrm{mg} / \mathrm{kg})$ & 830 & 520 & 280 & $<0.05$ & 300 \\
\hline Avena nula (mg/kg) & 820 & 1690 & 1050 & $0.030-0.145$ & 300 \\
\hline \multicolumn{6}{|l|}{ Copper } \\
\hline Water source (mg/L) & \multicolumn{3}{|c|}{0.196 (Wastewater) $^{b}$} & 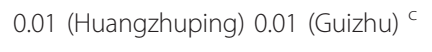 & 1.000 \\
\hline Irrigation water (mg/L) & 0.631 & 0.020 & 0.020 & $<0.01$ & 0.500 \\
\hline Well water (mg/L) & 1.570 & 0.020 & 0.045 & $<0.01$ & 1.00 \\
\hline Soil (mg/kg) & 1261 & 147 & 20 & $2.85-8.19$ & 100 \\
\hline Rice (mg/kg) & 5.38 & 3.08 & 2.03 & $0.43-0.69$ & 10 \\
\hline Avena nula (mg/kg) & 1.31 & 0.82 & 0.42 & $0.23-1.09$ & $-d$ \\
\hline \multicolumn{6}{|l|}{ Zinc } \\
\hline Water source (mg/L) & \multicolumn{3}{|c|}{13.700 (Wastewater) $^{\text {b }}$} & 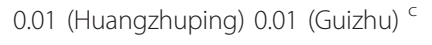 & 1.000 \\
\hline Irrigation water (mg/L) & 25.200 & 0.048 & 0.005 & $<0.01-0.84$ & 2.00 \\
\hline Well water (mg/L) & 4.89 & 0.024 & 0.011 & $<0.01-0.49$ & 1.00 \\
\hline Soil (mg/kg) & 680 & 227 & 68 & $2.85-8.19$ & 250 \\
\hline Rice (mg/kg) & 29.40 & 20.70 & 13.80 & $7.50-10.90$ & 50 \\
\hline Avena nula (mg/kg) & 20.80 & 5.12 & 3.73 & $2.89-7.94$ & $-d$ \\
\hline
\end{tabular}

a Government standard.

b Sampling point of wastewater [01] in the high-exposure area (see Figure 1).

' Sampling points of water source [02] and [03] in the low-exposure area (see Figure 1).

${ }^{\mathrm{d}}$ No government standard. 
characteristics among the nine studied villages. Our analysis showed that the percentage of residents consuming local produce among the HEA participants $(\mathrm{n}=563)$ was $96.1 \%$ and LEA participants ( $\mathrm{n}=589$ ) was $98.3 \%$. The consumption frequency of produce grown on local farms situated in the HEA is significantly lower than that in the LEA. There was no difference in the rate of cigarette smoking and alcohol consumption, and none of the women living in these villages had a smoking habit (data not shown).

Based on the dwelling time of the HEA participants ( $\mathrm{n}$ $=563$ ), the median duration of exposure to pollutants from Dabaoshan mine was 28 years. The geometric mean blood levels of $\mathrm{Cd}, \mathrm{Pb}, \mathrm{Cu}$ and $\mathrm{Zn}$ in subjects from the HEA were measured at $24.10 \mu \mathrm{g} / \mathrm{L}, 38.91 \mu \mathrm{g} /$ $\mathrm{dL}, 0.82 \mathrm{mg} / \mathrm{L}$ and $8.38 \mathrm{mg} / \mathrm{L}$, respectively (Table 2). The numbers of blood $\mathrm{Cd}$ and $\mathrm{Pb}$ levels of 1152 residents living in the HEA and LEA were represented in Additional file 1, 2, 3 and 4, figure s1-s4. The $\mathrm{Cd}$ and $\mathrm{Pb}$ levels were higher in the older subjects and highest in former smokers and alcohol drinkers. The mean blood concentrations of $\mathrm{Cd}, \mathrm{Pb}$ and $\mathrm{Zn}$ were also significantly elevated in comparison with the levels in the LEA residents, although the mean blood $\mathrm{Cu}$ concentrations were not significantly different among the two populations (See Additional file 5: table s1).

\section{Cancer mortality and rate ratio}

Of the 10,688,263 residents of the RAGDP evaluated in the third retrospective investigation, 71,912 deaths, including 14,635 cancer deaths, were recorded from 2004 to 2005 . Amongst the 761,224 residents of Wengyuan County, 4,904 deaths, including 1,080 cancer deaths, were recorded from 2004 to 2005. Of the 194,131 residents of the nine villages analyzed in our current study, 1,093 deaths, including 342 cancer deaths, were recorded from 2000-2007. The age-adjusted cancer mortality rates and the expected number of cancer deaths for both sexes, males and females were respectively calculated in each studied population (See Additional file 6, 7, 8 and 9; tables s2, s3, s4 and s5).

The rates of mortality from all types of cancer in the HEA were substantially elevated in comparison with the mortality rate in the LEA for both sexes [rate ratio $(R R)=2.32 ; 95 \%$ confidence interval $=1.87$ - 2.89), men (2.13; 1.63 - 2.77) and women $(2.83 ; 1.91$ - 4.19), compared with the corresponding rates in the whole of Wengyuan County among both sexes (1.92; 1.66 - 2.20), men $(1.81 ; 1.51-2.14)$ and women $(1.95$; 1.53 - 2.46). The cancer mortality rates in the HEA were also elevated compared with the rates in the RAGDP population among both sexes $(2.01 ; 1.74$ $2.30)$, men $(1.99 ; 1.65-2.35)$ and women $(2.12 ; 1.66-$ 2.67) (Table 3).
Not only all-cancer mortality rate, but also the mortality rates from esophageal-, stomach- and lung-cancer in the HEA were significantly elevated in comparison with the corresponding rates in the LEA, Wengyuan County and the RAGDP population for both sexes, men and women (Table 3).

The mortality rates from leukocythemia and nonHodgkin's lymphoma in the HEA were strongly elevated in comparison with these rates in the LEA, Wengyuan County and the RAGDP population, but among men only. In contrast, the mortality rates from liver cancer, kidney cancer and other cancers were not elevated in the HEA compared with the corresponding rates in the LEA, Wengyuan County, or the RAGDP population (Table 4).

\section{Relationships between heavy metal exposure and the risk of cancer mortality}

We initially found by using simple linear regression that exposures to $\mathrm{Cd}$ and $\mathrm{Pb}$ were associated, respectively, with increased risk of all types of cancer and stomach cancer among both the sexes combined and women, but that $\mathrm{Zn}$ exposure was not associated with the risk of site-specific cancer mortality (Table 5 and 6). Interestingly, further multiple linear regression analysis revealed that there was a negative correlation between exposure to $\mathrm{Pb}$ and the risk for all cancer mortality, and that no relationships existed between exposure to $\mathrm{Cd}$ and $\mathrm{Pb}$ and the risk of stomach cancer mortality among both the sexes combined and women, which was counterintuitive. Because there were strong correlations found between the blood $\mathrm{Cd}$ and $\mathrm{Pb}$ levels $\left(\mathrm{r}_{\text {men }}, \mathrm{Cd}-\mathrm{Pb}=0.927\right.$, and $\left.r_{\text {women }}, \mathrm{Cd}-\mathrm{Pb}=0.886\right)$ in the nine villages evaluated, collinearity needed to be considered as this can skew the observed relationships. We thus employed ridge regressions to analysis these relationships, which revealed that the blood $\mathrm{Cd}$ and $\mathrm{Pb}$ level exploratory variables have effects upon the age-adjusted mortality rates from all-cancer and stomach cancer among both the sexes combined and women, respectively.

\section{Discussion}

We have conducted a large, death certificate-based ecological epidemiological study using cause-specific cancer mortality ratios, and observed that long-term environmental exposure to $\mathrm{Cd}$ and $\mathrm{Pb}$ results, at least partly, in a substantial elevation in the risk of mortality from all cancers, in addition to, stomach, esophageal and lung cancer. Our data show that the exposure levels to metal contaminants were high in the HEA with the mean blood $\mathrm{Cd}$ concentration $(44.5 \mathrm{nmol} / \mathrm{L})$ found to be nearly 13 -fold and 5-fold higher, respectively, than that in the LEA and the maximum recommended by the Occupational Safety and Health Administration (OSHA) 
Table 2 Blood Levels of Cadmium, Lead, Copper and Zinc by Participant Characteristics

\begin{tabular}{|c|c|c|c|c|c|}
\hline \multirow[b]{2}{*}{ Characteristics } & \multirow[b]{2}{*}{ n } & \multicolumn{4}{|c|}{ Geometric mean (SD) } \\
\hline & & Cadmium, ug/L & Lead, $\mu \mathrm{g} / \mathrm{dL}$ & Copper, mg/L & Zinc, $\mathrm{mg} / \mathrm{L}$ \\
\hline The high-exposure area $(H)(I-\mid I I)$ & 563 & $24.10(3.52)^{a}$ & $38.91(0.39)^{a}$ & $0.82(1.49)$ & $8.38(1.96)^{a}$ \\
\hline Shangba (I) & 198 & $34.80(2.96)$ & $67.36(0.24)$ & $0.84(1.42)$ & $11.23(1.75)$ \\
\hline Xiaozhen(II) & 177 & $10.33(4.16)$ & $10.35(0.40)$ & $0.73(1.26)$ & $5.52(1.45)$ \\
\hline Dongfang (III) & 188 & $21.37(3.11)$ & $62.55(0.28)$ & $0.86(1.71)$ & $8.94(2.09)$ \\
\hline The low-exposure area (L) (IV-IX) & 589 & $1.87(2.48)^{a}$ & $4.46(0.18)^{a}$ & $0.81(1.24)$ & $7.96(1.32)^{a}$ \\
\hline Zhongxin (IV) & 172 & $1.69(2.34)$ & $5.81(0.17)$ & $0.86(1.27)$ & $8.47(1.34)$ \\
\hline Shaping $(V)$ & 72 & $2.06(2.57)$ & $4.70(0.18)$ & $0.81(1.16)$ & $7.80(1.30)$ \\
\hline Shuikou (VI) & 72 & $1.90(2.51)$ & $3.79(0.15)$ & $0.85(1.29)$ & $8.34(1.19)$ \\
\hline Fengshan (VII) & 104 & $1.23(2.45)$ & $4.34(0.18)$ & $0.79(1.14)$ & $8.17(1.24)$ \\
\hline Mashan (VIII) & 86 & $2.15(2.12)$ & $2.97(0.19)$ & $0.72(1.19)$ & $7.51(1.27)$ \\
\hline Madun (IX) & 83 & $3.03(2.40)$ & $4.47(0.15)$ & $0.76(1.25)$ & 7.01 (1.45) \\
\hline \multicolumn{6}{|l|}{ Age, yrs } \\
\hline \multicolumn{6}{|l|}{$18-39$} \\
\hline $\mathrm{H}$ & 106 & $24.47(3.15)$ & $39.98(0.42)$ & $0.78(1.34)$ & $8.10(1.95)$ \\
\hline L & 73 & $1.64(2.37)$ & $4.37(0.17)$ & $0.83(1.38)$ & $7.93(1.27)$ \\
\hline \multicolumn{6}{|l|}{$40-59$} \\
\hline $\mathrm{H}$ & 328 & $25.44(3.50)$ & $36.96(0.40)$ & $0.82(1.57)$ & 8.16 (1.93) \\
\hline L & 373 & $1.83(2.47)$ & $4.41(0.18)$ & $0.81(1.21)$ & 7.98 (1.33) \\
\hline \multicolumn{6}{|l|}{$60-74$} \\
\hline $\mathrm{H}$ & 99 & 23.09 (3.93) & $44.08(0.40)$ & $0.85(1.36)$ & $9.80(2.13)$ \\
\hline L & 97 & $2.12(2.66)$ & $4.55(0.17)$ & $0.79(1.22)$ & 7.99 (1.33) \\
\hline \multicolumn{6}{|l|}{$\geq 75$} \\
\hline $\mathrm{H}$ & 30 & $27.03(3.96)$ & $41.12(0.24)$ & $0.81(1.50)$ & $7.56(1.64)$ \\
\hline L & 46 & $2.11(2.24)$ & $4.73(0.20)$ & $0.82(1.25)$ & 7.79 (1.29) \\
\hline \multicolumn{6}{|l|}{ Smoking } \\
\hline \multicolumn{6}{|l|}{ Never } \\
\hline $\mathrm{H}$ & 436 & $24.40(3.58)$ & $37.72(0.40)$ & $0.80(1.40)$ & 8.15 (1.92) \\
\hline L & 392 & $1.43(2.11)$ & $4.15(0.18)$ & $0.82(1.22)$ & 7.89 (1.28) \\
\hline \multicolumn{6}{|l|}{ Former } \\
\hline $\mathrm{H}$ & 29 & $28.46(2.31)$ & $45.92(0.29)$ & $0.87(1.36)$ & 10.19 (1.97) \\
\hline L & 43 & $1.76(2.52)$ & $4.50(0.19)$ & $0.86(1.32)$ & $7.22(1.58)$ \\
\hline \multicolumn{6}{|l|}{ Current } \\
\hline $\mathrm{H}$ & 98 & $26.27(3.63)$ & $42.56(0.40)$ & $0.85(1.88)$ & $9.00(2.11)$ \\
\hline L & 154 & $3.79(2.46)$ & $5.31(0.17)$ & $0.77(1.24)$ & $8.34(1.33)$ \\
\hline \multicolumn{6}{|l|}{ Alcohol } \\
\hline \multicolumn{6}{|l|}{ Never } \\
\hline $\mathrm{H}$ & 364 & $23.55(3.57)$ & $39.71(0.39)$ & $0.82(1.52)$ & 8.27 (1.99) \\
\hline L & 332 & $1.77(2.37)$ & $4.24(0.18)$ & $0.82(1.24)$ & 7.95 (1.29) \\
\hline \multicolumn{6}{|l|}{ Former } \\
\hline $\mathrm{H}$ & 44 & $31.05(2.90)$ & $45.44(0.28)$ & $0.84(1.33)$ & $8.36(1.70)$ \\
\hline L & 46 & $1.91(2.55)$ & $4.24(0.15)$ & $0.86(1.32)$ & $7.16(1.56)$ \\
\hline \multicolumn{6}{|l|}{ Current } \\
\hline $\mathrm{H}$ & 155 & $26.70(3.58)$ & $35.50(0.43)$ & $0.81(1.47)$ & 8.67 (1.97) \\
\hline L & 211 & $2.03(2.63)$ & $4.86(0.17)$ & $0.78(1.20)$ & $8.15(1.30)$ \\
\hline
\end{tabular}

Safety Standard (5.0 $\mu \mathrm{g} / \mathrm{L})$ [37]. Moreover, the mean blood $\mathrm{Cd}$ concentration of the participants living in the HEA was nearly 2.5 -fold higher than that previously measured in workers with a 20-year cumulative cadmium exposure and showing a blood cadmium concentration of $10 \mu \mathrm{g} / \mathrm{L}$ [38]. The mean blood $\mathrm{Pb}$ level of the subjects in the HEA was found in previous occupational studies to be in the range of $26 \mu \mathrm{g} / \mathrm{dL}$ to $80 \mu \mathrm{g} /$ 
Table 3 Comparison of the cancer mortality rates (per 100,000) in high-exposure area (HEA) to those in low-exposure area (LEA), Wengyuan county and the rural areas of Guangdong Province (RAGDP)

\begin{tabular}{|c|c|c|c|c|c|c|c|c|c|c|c|c|c|}
\hline \multirow{2}{*}{$\begin{array}{l}\text { Population } \\
\text { (Years) }\end{array}$} & \multirow[b]{2}{*}{ Statistic } & \multicolumn{3}{|c|}{ All cancers } & \multicolumn{3}{|c|}{ Esophagus cancer } & \multicolumn{3}{|c|}{ Stomach cancer } & \multicolumn{3}{|c|}{ Lung cancer } \\
\hline & & Both & Men & Women & Both & Men & Women & Both & Men & Women & Both & Men & Women \\
\hline The HEA & $E^{a}$ & 194 & 125 & 68 & 30 & 17 & 13 & 60 & 34 & 26 & 36 & 24 & 12 \\
\hline$(2000-2007)$ & Rate $^{b}$ & 265.1 & 332.5 & 191.1 & 41.0 & 45.2 & 36.5 & 82.0 & 90.4 & 73.1 & 49.2 & 63.9 & 33.7 \\
\hline Comparison: & $E^{a}$ & 138 & 99 & 39 & 22 & 14 & 8 & 19 & 17 & 2 & 27 & 22 & 5 \\
\hline \multirow[t]{4}{*}{ The LEA (2000-2007) } & Rate $^{b}$ & $\begin{array}{l}5 \\
114.1\end{array}$ & 156.3 & 67.7 & 18.2 & 22.1 & 13.9 & 15.7 & 26.9 & 3.5 & 22.3 & 34.7 & 8.7 \\
\hline & $\begin{array}{l}\text { Rate } \\
\text { ratio }^{c}\end{array}$ & 2.32 & 2.13 & 2.83 & 2.25 & 2.05 & 2.63 & 5.28 & 3.37 & 21.06 & 2.20 & 1.84 & 3.89 \\
\hline & $95 \% \mathrm{Cl}^{\mathrm{d}}$ & $\begin{array}{l}1.87- \\
2.89\end{array}$ & $\begin{array}{l}1.63- \\
2.77\end{array}$ & $\begin{array}{l}1.91- \\
4.19\end{array}$ & $\begin{array}{l}1.30- \\
3.91\end{array}$ & $\begin{array}{l}1.01- \\
4.15\end{array}$ & $\begin{array}{l}1.09- \\
6.35\end{array}$ & $\begin{array}{l}3.12- \\
8.74\end{array}$ & $\begin{array}{l}1.88- \\
6.03\end{array}$ & $\begin{array}{l}5.00- \\
88.71\end{array}$ & $\begin{array}{l}1.34- \\
3.63\end{array}$ & $\begin{array}{l}1.03- \\
3.28\end{array}$ & $\begin{array}{l}1.37- \\
11.03\end{array}$ \\
\hline & $P^{d}$ & $<0.001$ & $<0.001$ & $<0.001$ & 0.003 & 0.043 & 0.025 & $<0.001$ & $<0.001$ & $<0.001$ & 0.001 & 0.036 & 0.006 \\
\hline \multirow{4}{*}{$\begin{array}{l}\text { Comparison: Wengyuan } \\
\text { County (2004-2005) }\end{array}$} & Rate $^{\dagger}$ & 138.3 & 183.5 & 98.0 & 17.0 & 16.1 & 17.6 & 37.0 & 48.6 & 26.4 & 22.2 & 38.0 & 10.3 \\
\hline & $\begin{array}{l}\text { Rate } \\
\text { ratio }^{c}\end{array}$ & 1.92 & 1.81 & 1.95 & 2.41 & 2.81 & 2.08 & 2.22 & 1.86 & 2.77 & 2.22 & 1.68 & 3.27 \\
\hline & $95 \% \mathrm{Cl}^{\mathrm{e}}$ & $\begin{array}{l}1.66- \\
2.20\end{array}$ & $\begin{array}{l}1.51- \\
2.14\end{array}$ & $\begin{array}{l}1.53- \\
2.46\end{array}$ & $\begin{array}{l}1.66- \\
3.40\end{array}$ & $\begin{array}{l}1.69- \\
4.41\end{array}$ & $\begin{array}{l}1.16- \\
3.46\end{array}$ & $\begin{array}{l}1.71- \\
2.83\end{array}$ & $\begin{array}{l}1.31- \\
2.57\end{array}$ & $\begin{array}{l}1.85- \\
4.00\end{array}$ & $\begin{array}{l}1.58- \\
3.04\end{array}$ & $\begin{array}{l}1.10- \\
2.46\end{array}$ & $\begin{array}{l}1.77- \\
5.56\end{array}$ \\
\hline & $p^{e}$ & $<0.001$ & $<0.001$ & $<0.001$ & $<0.001$ & $<0.001$ & 0.017 & $<0.001$ & 0.001 & $<0.001$ & $<0.001$ & 0.018 & 0.001 \\
\hline \multirow{4}{*}{$\begin{array}{l}\text { Comparison: the RAGDP (2004- } \\
\text { 2005) }\end{array}$} & Rate $^{\dagger}$ & 131.8 & 167.3 & 90.3 & 11.8 & 16.7 & 7.1 & 15.0 & 20.4 & 9.9 & 26.6 & 39.8 & 14.6 \\
\hline & $\begin{array}{l}\text { Rate } \\
\text { ratio }^{c}\end{array}$ & 2.01 & 1.99 & 2.12 & 3.48 & 2.71 & 5.14 & 5.46 & 4.43 & 7.73 & 1.85 & 1.61 & 2.31 \\
\hline & $95 \% \mathrm{Cl}^{\mathrm{e}}$ & $\begin{array}{l}1.74- \\
2.30\end{array}$ & $\begin{array}{l}1.65- \\
2.35\end{array}$ & $\begin{array}{l}1.66- \\
2.67\end{array}$ & $\begin{array}{l}2.39- \\
4.90\end{array}$ & $\begin{array}{l}1.63- \\
4.25\end{array}$ & $\begin{array}{l}2.86- \\
8.57\end{array}$ & $\begin{array}{l}4.21- \\
6.99\end{array}$ & $\begin{array}{l}3.12- \\
6.12\end{array}$ & $\begin{array}{l}4.91- \\
10.64\end{array}$ & $\begin{array}{l}1.32- \\
2.53\end{array}$ & $\begin{array}{l}1.05- \\
2.35\end{array}$ & $\begin{array}{l}1.25- \\
3.92\end{array}$ \\
\hline & $p^{e}$ & $<0.001$ & $<0.001$ & $<0.001$ & $<0.001$ & $<0.001$ & $<0.001$ & $<0.001$ & $<0.001$ & $<0.001$ & 0.001 & 0.030 & 0.010 \\
\hline
\end{tabular}

${ }^{a}$ Expected deaths; round to nearest whole number for statistical calculations based on the binomial distribution.

${ }^{b}$ Calculated by the expected deaths in study regions by the total populations of men or women or both in Additional file 6 table s2.

${ }^{c}$ Calculated by dividing the rate in the exposed regions by the rate in the comparison populations.

${ }^{d}$ Exact mid- $P$ 95\% Cls and two-side hypothesis test probabilities $(P)$ were calculated with PEPI Compare2 program.

e The exact $\mathrm{Cl}$ and $P$ were calculated using PEPI Describe for the Poisson statistical distribution.

$\mathrm{dL}[11,39]$. The duration of exposure was about 30 years among individuals who suffered cancer-related deaths in the HEA in our present study, with a median age of death from stomach cancer for males and females of 73 and 66 years, respectively.

Although the mean blood $\mathrm{Zn}$ concentration of the participants living in the HEA was significantly higher than that found in the LEA, further analysis indicated that there was no association between $\mathrm{Zn}$ exposure and site-specific cancer mortality. This result is consistent with a previous study showing no evidence for an association between $\mathrm{Zn}$ exposure and an increased human cancer risk, particularly for lung or stomach cancer [10].

There is now strong evidence for a positive association between occupational $\mathrm{Cd}$ exposure alone and lung cancer risk, and a recent cohort study in an area of lowlevel Cd pollution in Belgium has reported a significantly positive association between urinary cadmium (U-Cd) levels and the incidence of all cancer and lung cancer in the local population [40]. However, a few population-based studies in Japan have reported inconsistent results in this regard [41-43]. Two further studies on the general population in the United States have shown that $\mathrm{U}-\mathrm{Cd}$ levels of $0.28 \mu \mathrm{g} / \mathrm{g}$ creatinine in men and blood $\mathrm{Pb}$ levels of 5-9 $\mu \mathrm{g} / \mathrm{dL}$ could, respectively, significantly increase the risk of death from all cancer $[44,45]$. However, whether lead causes cancer has not been definitively established [8,39]. The site-specific cancers reported to be associated with lead exposure vary among epidemiological studies. Two previous meta-analysis studies $[11,39]$ have indicated that occupational $\mathrm{Pb}$ exposure is associated with an increased risk of all cancer, lung cancer and stomach cancer, but little evidence has been found for an increased risk of kidney or brain cancer from $\mathrm{Pb}$.

Similar to previous analyses, our present findings indicate that the rate of mortality from all types of cancer in the HEA among both sexes, men and women were substantially elevated in comparison with those of the LEA, the whole of Wengyuan County and the RAGDP population. At the population level, our analyses showed not only that $\mathrm{Cd}$ exposure but also that $\mathrm{Pb}$ exposure was significantly positively correlated with all-cancer mortality among both the sexes combined and women. 
Table 4 Comparison of the cancer mortality rates (per 100,000) in high-exposure area (HEA) to those in low-exposure area (LEA), Wengyuan county and the rural areas of Guangdong Province (RAGDP)

\begin{tabular}{|c|c|c|c|c|c|c|c|c|c|c|c|c|c|}
\hline \multirow{2}{*}{$\begin{array}{l}\text { Population } \\
\text { (Years) }\end{array}$} & \multirow[b]{2}{*}{ Statistic } & \multicolumn{3}{|c|}{ Liver cancer } & \multicolumn{3}{|c|}{ Leukocythemia } & \multicolumn{3}{|c|}{ Non-Hodgin disease } & \multicolumn{3}{|c|}{ Other cancers ${ }^{f}$} \\
\hline & & Both & Men & Women & Both & Men & Women & Both & Men & Women & Both & Men & Women \\
\hline The HEA & $E^{a}$ & 38 & 27 & 11 & 8 & 7 & 1 & 4 & 3 & 1 & 21 & 14 & 7 \\
\hline$(2000-2007)$ & Rate $^{b}$ & 51.9 & 71.8 & 30.9 & 10.9 & 18.6 & 2.8 & 5.5 & 8.0 & 2.8 & 28.7 & 37.2 & 19.7 \\
\hline Comparison: & $E^{a}$ & 39 & 28 & 11 & 7 & 4 & 4 & 0 & 0 & 0 & 23 & 13 & 10 \\
\hline The LEA & Rate $^{b}$ & 32.2 & 44.3 & 19.1 & 5.8 & 6.3 & 6.9 & 0 & 0 & 0 & 19.0 & 20.5 & 17.4 \\
\hline \multirow[t]{3}{*}{$(2000-2007)$} & $\begin{array}{l}\text { Rate } \\
\text { ratio }^{c}\end{array}$ & 1.61 & 1.62 & 1.62 & 1.89 & 2.95 & 0.41 & - & - & - & 1.51 & 1.81 & 1.13 \\
\hline & $95 \% \mathrm{Cl}^{d}$ & $\begin{array}{l}1.03- \\
2.52\end{array}$ & $\begin{array}{l}0.96- \\
2.75\end{array}$ & $\begin{array}{l}0.70- \\
3.74\end{array}$ & $\begin{array}{l}0.69- \\
5.21\end{array}$ & $\begin{array}{l}0.86- \\
10.1\end{array}$ & $\begin{array}{l}0.05- \\
3.62\end{array}$ & - & - & - & $\begin{array}{l}0.84- \\
2.73\end{array}$ & $\begin{array}{l}0.85- \\
3.86\end{array}$ & $\begin{array}{l}0.43- \\
2.98\end{array}$ \\
\hline & $P^{d}$ & 0.035 & 0.070 & 0.254 & 0.211 & 0.070 & 0.403 & - & - & - & 0.170 & 0.117 & 0.799 \\
\hline \multirow{4}{*}{$\begin{array}{l}\text { Comparison: Wengyuan County } \\
\text { (2004-2005) }\end{array}$} & Rate $^{+}$ & 42.3 & 64.0 & 21.5 & 4.5 & 5.2 & 3.8 & 1.2 & 1.3 & 1.1 & 16.1 & 10.3 & 17.3 \\
\hline & $\begin{array}{l}\text { Rate } \\
\text { ratio }^{c}\end{array}$ & 1.23 & 1.12 & 1.44 & 2.43 & 3.58 & 0.74 & 4.58 & 6.15 & 2.55 & 1.78 & 3.61 & 1.14 \\
\hline & $95 \% \mathrm{Cl}^{\mathrm{e}}$ & $\begin{array}{l}0.88- \\
1.67\end{array}$ & $\begin{array}{l}0.75- \\
1.61\end{array}$ & $\begin{array}{l}0.76- \\
2.50\end{array}$ & $\begin{array}{l}1.13- \\
4.62\end{array}$ & $\begin{array}{l}1.57- \\
7.10\end{array}$ & $\begin{array}{l}0.04- \\
3.65\end{array}$ & $\begin{array}{l}1.44- \\
11.0\end{array}$ & $\begin{array}{l}1.56- \\
16.7\end{array}$ & $\begin{array}{l}0.13- \\
12.64\end{array}$ & $\begin{array}{l}1.11- \\
2.63\end{array}$ & $\begin{array}{l}1.99- \\
5.73\end{array}$ & $\begin{array}{l}0.51- \\
2.31\end{array}$ \\
\hline & $p^{e}$ & 0.209 & 0.526 & 0.239 & 0.026 & 0.005 & 0.868 & 0.002 & 0.015 & 0.382 & 0.018 & $<0.001$ & 0.650 \\
\hline \multirow{4}{*}{$\begin{array}{l}\text { Comparison: the RAGDP (2004- } \\
\text { 2005) }\end{array}$} & Rate $^{+}$ & 39.8 & 63.1 & 16.7 & 4.0 & 4.2 & 3.8 & 1.8 & 2.3 & 1.3 & 32.8 & 20.8 & 36.9 \\
\hline & $\begin{array}{l}\text { Rate } \\
\text { ratio }\end{array}$ & 1.30 & 1.14 & 1.85 & 2.73 & 4.41 & 0.74 & 3.06 & 3.48 & 2.15 & 0.88 & 1.79 & 0.53 \\
\hline & $95 \% \mathrm{Cl}^{\mathrm{e}}$ & $\begin{array}{l}0.94- \\
1.77\end{array}$ & $\begin{array}{l}0.77- \\
1.63\end{array}$ & $\begin{array}{l}0.97- \\
3.22\end{array}$ & $\begin{array}{l}1.27- \\
5.18\end{array}$ & $\begin{array}{l}1.94- \\
8.76\end{array}$ & $\begin{array}{l}0.04- \\
3.65\end{array}$ & $\begin{array}{l}0.95- \\
7.20\end{array}$ & $\begin{array}{l}0.89- \\
9.49\end{array}$ & $\begin{array}{l}0.11- \\
10.72\end{array}$ & $\begin{array}{l}0.56- \\
1.31\end{array}$ & $\begin{array}{l}1.00- \\
2.87\end{array}$ & $\begin{array}{l}0.24- \\
1.07\end{array}$ \\
\hline & $p^{e}$ & 0.110 & 0.483 & 0.059 & 0.014 & 0.001 & 0.868 & 0.059 & 0.068 & 0.447 & 0.557 & 0.051 & 0.080 \\
\hline
\end{tabular}

${ }^{a}$ Expected deaths; round to nearest whole number for statistical calculations based on the binomial distribution.

${ }^{b}$ Calculated by the expected deaths in study regions by the total populations of men or women or both in Additional file 6 table $s 2$.

c Calculated by dividing the rate in the exposed regions by the rate in the comparison populations.

${ }^{\mathrm{d}}$ Exact mid- $P$ 95\% Cls and two-side hypothesis test probabilities $(P)$ were calculated with PEPI Compare2 program.

e The exact $\mathrm{Cl}$ and $P$ were calculated using PEPI Describe for the Poisson statistical distribution.

${ }^{f}$ Excluding the cases of leukocythemia and non-Hodgin disease.

Table 5 Estimation of the age-adjusted mortality risk for the selected specific cause associated with blood heavy metals levels for both sexes using simple, multiple linear and ridge regression in the nine villages evaluated in this study

\begin{tabular}{|c|c|c|c|c|c|c|c|c|c|c|}
\hline & \multicolumn{10}{|c|}{ Both sexes $^{a}$} \\
\hline & \multicolumn{2}{|c|}{ All cancer } & & \multicolumn{2}{|c|}{ Esophageal cancer } & & \multicolumn{2}{|c|}{ Stomach cancer } & \multicolumn{2}{|c|}{ Lung cancer } \\
\hline & $\mathrm{B}^{\mathrm{b}}$ & $\mathbf{P}$ & & $B^{b}$ & $P$ & & $B^{b}$ & $P$ & $B^{b}$ & $P$ \\
\hline $\mathrm{Cd}$ & 0.301 & $0.002^{c}$ & & 0.082 & 0.770 & & 0.584 & $0.012^{c}$ & 0.279 & 0.062 \\
\hline $\mathrm{Pb}$ & 0.260 & $0.039^{c}$ & & -0.045 & 0.881 & & 0.559 & $0.046^{c}$ & 0.263 & 0.117 \\
\hline \multirow[t]{4}{*}{$\mathrm{Zn}$} & -0.119 & 0.900 & & 0.134 & 0.944 & & 0.102 & 0.963 & 0.107 & 0.929 \\
\hline & \multicolumn{10}{|c|}{ Both sexes $^{d}$} \\
\hline & \multicolumn{5}{|c|}{ All cancers } & \multicolumn{5}{|c|}{ Stomach cancer } \\
\hline & $B^{c}$ & $P$ & Tolerance $^{\mathrm{e}}$ & VIF $^{f}$ & RRC $^{\mathrm{j}}$ & $B^{c}$ & $P$ & Tolerance $^{\mathrm{e}}$ & VIF $^{f}$ & RRC $^{\mathrm{h}}$ \\
\hline $\mathrm{Cd}$ & 0.483 & $0.018^{c}$ & 0.172 & 5.826 & 0.376616 & 0.723 & 0.156 & 0.168 & 5.964 & 0.303854 \\
\hline $\mathrm{Pb}$ & -0.216 & 0.228 & 0.172 & 5.826 & 0.188513 & -0.168 & 0.739 & 0.168 & 5.964 & 0.440660 \\
\hline
\end{tabular}

${ }^{a}$ using simple linear regression.

${ }^{\mathrm{b}}$ Estimate of the regression coefficient of log-transformed for blood cadmium, lead and zinc levels by using simple linear regression.

c $P<0.05$.

${ }^{d}$ Estimate of the regression coefficient of the relationships between log-transformed for blood cadmium and lead levels and log-transformed for age-adjusted mortality rates from all-cancer and stomach cancer using multiple linear regression and estimate of the regression coefficient of the relationships log-transformed for blood cadmium, lead and zinc levels and the original age-adjusted mortality rates from all-cancer and stomach cancer using ridge regression.

e A tolerance $<0.10$ indicates that collinearity must be considered.

${ }^{f}$ Variance inflation factor; If $>10$, collinearity must be considered.

j Ridge regression coefficients; a Ridge $k$ of 0.85 and RSQ of 0.60815 were caiculated using ridge regression.

${ }^{\mathrm{h}}$ Ridge regression coefficients; a Ridge $k$ of 0.40 and RSQ of 0.66049 were caiculated using ridge regression. 
Table 6 Estimation of the age-adjusted mortality risk for the selected specific cause associated with blood heavy metals levels for women and men separately using simple, multiple linear and ridge regression in the nine villages evaluated in this study

\begin{tabular}{|c|c|c|c|c|c|c|c|c|c|c|c|c|c|c|c|c|}
\hline & \multicolumn{8}{|c|}{ Women $^{a}$} & \multicolumn{8}{|c|}{ Men $^{a}$} \\
\hline & \multicolumn{2}{|c|}{ All cancer } & \multicolumn{2}{|c|}{ Esophageal cancer } & \multicolumn{2}{|c|}{$\begin{array}{c}\text { Stomach } \\
\text { cancer }\end{array}$} & \multicolumn{2}{|c|}{ Lung cancer } & \multicolumn{2}{|c|}{ All cancers } & \multicolumn{2}{|c|}{ Esophageal cancer } & \multicolumn{2}{|c|}{$\begin{array}{c}\text { Stomach } \\
\text { cancer }\end{array}$} & \multicolumn{2}{|c|}{ Lung cancer } \\
\hline & $B^{b}$ & $\mathbf{P}$ & $B^{b}$ & $P$ & $\mathrm{~B}^{\mathrm{b}}$ & $P$ & $B^{b}$ & $\mathbf{P}$ & $\mathrm{B}^{\mathrm{b}}$ & $\mathbf{P}$ & $B^{b}$ & $P$ & $B^{b}$ & $\mathrm{P}$ & $\mathrm{B}^{\mathrm{b}}$ & $\mathbf{P}$ \\
\hline$\overline{\mathrm{Cd}}$ & 0.365 & $0.001^{c}$ & 0.204 & 0.286 & 0.549 & $0.037^{c}$ & 0.324 & 0.067 & 0.276 & 0.062 & 0.472 & 0.071 & 0.558 & 0.070 & 0.163 & 0.493 \\
\hline $\mathrm{Pb}$ & 0.374 & $0.026^{c}$ & 0.175 & 0.476 & 0.684 & $0.020^{c}$ & 0.275 & 0.272 & 0.221 & 0.101 & 0.411 & 0.624 & 0.424 & 0.151 & 0.194 & 0.350 \\
\hline $\mathrm{Zn}$ & -0.034 & 0.977 & 1.361 & 0.323 & 0.943 & 0.691 & 0.444 & 0.759 & -0.366 & 0.718 & 0.235 & 0.893 & -0.280 & 0.898 & -0.312 & 0.831 \\
\hline & \multicolumn{16}{|c|}{ Women $^{d}$} \\
\hline & \multicolumn{8}{|c|}{ All cancers } & \multicolumn{8}{|c|}{ Stomach cancer } \\
\hline & $B^{c}$ & $P$ & & Tolerance $^{\mathrm{e}}$ & & VIF $^{f}$ & $\mathrm{RRC}^{\mathrm{j}}$ & & $B^{c}$ & $P$ & & Tolerance $^{\mathrm{e}}$ & & VIF $^{f}$ & $\mathrm{RRC}^{\mathrm{h}}$ & \\
\hline$\overline{\mathrm{Cd}}$ & 0.491 & $0.024^{c}$ & & 0.197 & & 5.073 & 0.469722 & & 0.221 & 0.491 & & 0.245 & & 4.075 & 0.454158 & \\
\hline $\mathrm{Pb}$ & -0.175 & 0.424 & & 0.197 & & 5.073 & 0.205384 & & 0.453 & 0.291 & & 0.245 & & 4.075 & 0.342160 & \\
\hline
\end{tabular}

a using simple linear regression.

${ }^{b}$ Estimate of the regression coefficient of log-transformed for blood cadmium, lead and zinc levels by using simple linear regression.

${ }^{c} P<0.05$.

${ }^{d}$ Estimate of the regression coefficient of the relationships between log-transformed for blood cadmium and lead levels and log-transformed for age-adjusted mortality rates from all-cancer and stomach cancer using multiple linear regression and estimate of the regression coefficient of the relationships between logtransformed for blood cadmium, lead and zinc levels and the original age-adjusted mortality rates from all-cancer and stomach cancer using ridge regression.

e A tolerance $<0.10$ indicates that collinearity must be considered.

${ }^{f}$ Variance inflation factor; If $>10$, collinearity must be considered.

${ }^{j}$ Ridge regression coefficients; a Ridge $k$ of 0.50 and RSQ of 0.69853 were calculated using ridge regression.

${ }^{\mathrm{h}}$ Ridge regression coefficients; a Ridge $k$ of 0.10 and RSQ of 0.66647 were calculated using ridge regression.

Moreover, Cd exposure showed a borderline statistically significant correlation with all-cancer mortality among men $(P=0.062$; Table 6$)$. However, the significantly elevated all-cancer mortality rate could not be distinguished from independent effects or joint action resulting from $\mathrm{Cd}$ and $\mathrm{Pb}$.

In terms of specific cancers, the rates of mortality from stomach cancer in the HEA among both sexes, men and women was substantially elevated in comparison with the corresponding rates the LEA, and the Wengyuan county and RAGDP populations. Only one previous cohort study [46] has reported a statistically significant positive association between occupational $\mathrm{Cd}$ exposure and stomach cancer mortality $(\mathrm{SMR}=139$; 95\% CI, 111-166). Previous meta-analyses have reported that a high occupational $\mathrm{Pb}$ exposure is associated with an increased risk of stomach cancer [risk ratio $(R R)=$ 1.33, 95\% CI, 1.18-1.49 and RR $=1.34,95 \% \mathrm{CI}, 1.14$ 1.57, respectively]. To date however, there has been no substantial evidence of the association between dietary $\mathrm{Cd}$ or $\mathrm{Pb}$ intake and risk of stomach cancer mortality in the general population $[15,45]$. This could be attributed to different exposure pathways, exposure doses and threshold effects. A study by Jemal et al (2002) has reported a threshold effect in women, with the cancer risk becoming significantly elevated at a blood $\mathrm{Pb}$ concentration of approximately $24 \mu \mathrm{g} / \mathrm{dL}$ [47].

Potential risk factors for stomach cancer in China include Helicobacter Pylori (H. Pylori) infection of the stomach, a family history of stomach cancer, smoking, alcohol, consumption of salted foods, and a low intake of green vegetables and fruit, vitamin $\mathrm{C}$, and calcium [48]. Although individual-level confounding factors could not be controlled for in the present study, such as Helicobacter Pylori infection of the stomach, smoking or excessive drinking, the populations in the HEA and LEA showed similar SES, dietary and geographic characteristics, which may limit any potential biases. In particular, women generally did not have smoking or drinking habits in the Hengshihe River regions. In addition, the two reference populations were representative of the average and age-adjusted stomach cancer mortality rates resulting from all potential risk factors. Although there might be other potential risk factors, further analysis at the population level showed that $\mathrm{Cd}$ and $\mathrm{Pb}$ exposures were associated, respectively, with a significantly increased rate of stomach cancer among both the sexes combined and women and that $\mathrm{Cd}$ exposure had a borderline statistically significant correlation with all-cancer mortality among men $(P=0.070$, Table 6$)$. Hence, our findings revealed a strong association between stomach cancer risk and environmental exposure to both $\mathrm{Cd}$ and $\mathrm{Pb}$, but additional follow up studies focusing on both heavy metals are necessary to confirm these relationships.

To date, there has been no strong evidence for an association between dietary $\mathrm{Cd}$ or $\mathrm{Pb}$ intake and the risk of esophageal cancer mortality in the general population 
$[15,45]$. One study has reported that the incidence of malignant tumors in Nanao island in the South China sea has markedly increased during the period 19952003, particularly esophageal cancer $\left(71.07 / 10^{5}\right)$ and cardiac cancer $\left(34.59 / 10^{5}\right)$ [49]. Element analysis has also shown that the levels of $\mathrm{Pb}$ and $\mathrm{Cd}$ in the hair in a Nanao high-risk population were higher than those in a Meizhou Hakka control population, which may indicate a possible association with esophageal cancer risk. In terms of the associations between $\mathrm{Cd}$ and $\mathrm{Pb}$ exposure and esophageal cancer mortality in the HEA in our present report, the low $\mathrm{pH}$ of source water samples and water from some wells may be potential confounding factors. The low $\mathrm{pH}$ values for the water and soil also increase $\mathrm{Cd}$ and $\mathrm{Pb}$ bioavailability. The softer waters in the HEA are acidic in character and could well contain a number of toxic substances greatly in excess of the levels presented, such as $\mathrm{Cd}$ and $\mathrm{Pb}$. In addition, soft water is more corrosive than hard water and promotes the dissolution of $\mathrm{Cd}$ and $\mathrm{Pb}$ from contaminated water sources [50]. Hence, the presence of soft water in combination with exposure to both $\mathrm{Cd}$ and $\mathrm{Pb}$ might further increase the risk of carcinogenicity and play a role in esophageal cancer etiology. A $42 \%$ excess risk of mortality from esophageal cancer in relation to the use of soft water (adjusted odds ratio and 95\% confidence intervals; $1.42(1.22-1.66))$ has been reported in a study on Taiwan's drinking water [51]. Further studies will be required however to validate these phenomena. It is noteworthy also that some potential risk factors related to esophageal cancer, such as smoking, drinking, a low SES, poor nutrition, family history, human papillomavirus (HPV) infection and p53 mutations [52] could not be controlled for in our present study. At the population level, however, our analyses show that $\mathrm{Cd}$ exposure has a borderline statistically significant correlation with esophageal cancer mortality among men $(P=0.071$, Table $6)$. Therefore, our findings suggest a possible association between exposure to $\mathrm{Cd}$ and $\mathrm{Pb}$ and the risk of esophageal cancer mortality in a local environment. Due to its high occurrence in the HEA, esophageal cancer mortality should be further investigated using a cohort study.

With respect to lung cancer, and similar to previous analysis, our current study demonstrates that a longterm environmental exposure to both $\mathrm{Cd}$ and $\mathrm{Pb}$ is associated with an elevated risk of lung cancer. The main known risk factors for lung cancer are cigarette smoking, occupational exposure to toxic substances, environmental pollution, genetic polymorphisms, a family history of lung cancer and other tumor and respiratory system diseases [53]. Although these risk factors could not be controlled for in our present analysis, other potential risk factors were equivalent in the HEA and LEA populations, such as language, a similar SES and geographic characteristics, little occupational exposures and low air pollution. Moreover, at the population level, our analyses show that Cd exposure has a borderline statistically significant correlation with lung cancer mortality among the sexes combined $(P=0.062$, Table $5)$ and women $(P=0.067$, Table 6$)$. Hence, our data reporting a strong association between long-term environmental exposure to $\mathrm{Cd}$ and $\mathrm{Pb}$ and lung cancer risk are valid, but further cohort studies are necessary to make a definitive conclusion.

In our present investigation, a significant mortality increase from leukocythemia and non-Hodgkin's lymphoma was found among men only (Table 4). Seven deaths occurred from leukocythemia (ICD-10; C91-95) and three from non-Hodgkin's lymphoma (ICD-10; C82-85) in the HEA for men. Only one previous study has shown that occupational $\mathrm{Cd}$ exposure is linked to tumors of the hematopoietic system [54]. Oral exposure to $\mathrm{Cd}$ has also been reported to induce tumors of the hematopoietic system in rats and mice [55]. Thus, the available data seem to suggest a potential association between the exposure to $\mathrm{Cd}$ and $\mathrm{Pb}$ and tumors of the hematopoietic system among men only. However, it should be noted that number of deaths among men in our current cohorts was small, and potential confounding factors in some of these deaths could not be ruled out. One of the known risk factors for tumors of the hematopoietic system is Epstein-Barr virus infection $[56,57]$. Moreover, the development of leukemia is a complex process involving many risk factors, such as diagnostic X-rays, the history of occupational exposure of organic solvents $(2.56,1.03-6.39)$, the moving interval after house decoration $(1.67,1.173-2.39)$, the years of oxidant hair dye use (1.68, 1.04-2.70), and smoking and pesticide application $[58,59]$. Such information was not available in the present study and further cohort studies are necessary to confirm these relationships.

No increase in mortality from liver, kidney, bladder, brain or prostate cancer was found in the present study. One meta-analysis report has commented that increases in kidney and bladder cancer reported in the literature could have been the result of publication bias. The only way to resolve this issue is to conduct a comprehensive meta-analysis based on the data available from all relevant studies (published or otherwise).

Several limitations of our present study need to be mentioned. First, there may be an ecological fallacy, which means the same relationship exists among all of the individuals tested [60]. An individual-level confounding factor is particularly difficult to control and may have affected the results. However, an ecological study is especially useful when individual data are unavailable or are unlikely to be accurately reported by individual respondents because of an older age or lack of 
education. Second, there was a lack of more detailed cancer risk factor information for the studied population. Third, a larger number of observed cancer deaths will still be required to validate our results. Fourth, single blood measurements of multiple heavy metals, which are imperfect biomarkers of chronic exposure, were used in our analyses. Environmental exposures, however, are likely to be less changeable than occupational exposures, particularly for long-term local residents of the nine studied villages. Moreover, population studies are frequently based on single blood levels $[45,61,62]$. Fifth, our present examination of the correlations between exposure to multiple heavy metals and the risk of sitespecific cancer mortality in the nine studied villages provides only indirect evidence of the potential risk factors related to cancer. The blood metal concentrations may be variable and may not be representative of the population dying of cancer during observation period.

Despite these limitations however, our current study does address the public concern about whether the detrimental effects of heavy metal pollution are higher in the areas around the Dabaoshan mine than in other rural areas. Many sources of drinking and irrigation water have been contaminated by multiple heavy metals, such as $\mathrm{Cd}$ and $\mathrm{Pb}$, with advent of industrialization especially in developing countries like China [63]. Such contaminations have become a serious health hazard for millions of people. In addition, a cross-sectional study showed that some residents noted the risk of heavymetal pollution and did not consume produce grown on the local farms in the HEA. Based on our findings therefore, effective and preventive measures must be immediately taken in some of the polluted areas, such as improvements to the production process to better control pollution sources, to ban the drinking and use of contaminated water, the building of a new water reservoir and new management of soil and planting economic crops replacing agriculture crops.

The strengths of our current study stem from the death certificate-based retrospective mortality approach and the use of a population with a documented longterm environmental exposure to heavy metals. Furthermore, blood $\mathrm{Cd}$ and $\mathrm{Pb}$ concentrations are biomarkers of internal doses, which integrate all routes of exposure. Following long-term exposure to low levels of environmental $\mathrm{Cd}$, the blood $\mathrm{Cd}$ concentration may be a good indicator of the total $\mathrm{Cd}$ body burden [64].

\section{Conclusions}

Our current findings reveal a strong association between long-term environmental exposure to $\mathrm{Cd}$ and $\mathrm{Pb}$ and an increased risk of esophageal-cancer, stomach- and lung-, and all cancer mortality, although our ecological mortality study design does not allow for firm conclusions to be drawn at this time. Although further research is required to explore the effects of multiple heavy metals on cancer risk based on cohort studies, our study provides useful new insights into the causes of several types of cancer mortality and the possibility of reducing these risks through environmental interventions.

\section{Additional material}

Additional file 1: The number of blood Cd levels ( $\mu \mathrm{g} / \mathrm{L}$ ) in the residents living in the high-exposure area. The figure provided the number of blood $\mathrm{Cd}$ levels in the residents living in the high-exposure area of this study.

Additional file 2: The number of blood Pd levels $(\mu \mathrm{g} / \mathrm{dL}$ ) in the residents living in the high-exposure area. The figure provided the number of blood Pd levels in the residents living in the high-exposure area of this study.

Additional file 3: The number of blood Cd levels $(\mu \mathrm{g} / \mathrm{L}$ ) in the residents living in the low-exposure area. The figure provided the number of blood $\mathrm{Cd}$ levels in the residents living in the low-exposure area of this study.

Additional file 4: The number of blood Pd levels $(\mu \mathrm{g} / \mathrm{dL}$ ) in the residents living in the low-exposure area. The figure provided the number of blood Pd levels in the residents living in the low-exposure area of this study.

Additional file 5: Blood levels of cadmium, lead, copper and zinc in study subpopulations presented by participant characteristics. The table described the blood levels of cadmium, lead, copper and zinc in study subpopulations by participant characteristics, including sex and each village.

Additional file 6: The study populations in the mortality observation period were supplied from the Centre for Disease Control and Prevention of Wengyuan County in 2008. The table showed the number of the study populations in the mortality observation period of this study.

Additional file 7: Mortality data for all subjects from the study regions near the Dabaoshan mine for which the cancer rates (per 100,000 ) for $2000-2007$ as calculated in the present study. The table showed the mortality data for all subjects, including observed deaths, crude rate, age-adjusted rate and expected deaths, from the study regions near the Dabaoshan mine for which the cancer rates for 2000 2007 as calculated of this study.

Additional file 8: Mortality data for men from the study regions near the Dabaoshan mine for which the cancer rates (per 100,000) for 2000-2007 as calculated in the present study. The table showed the mortality data for men, including observed deaths, crude rate, ageadjusted rate and expected deaths, from the study regions near the Dabaoshan mine for which the cancer rates for 2000-2007 as calculated of this study.

Additional file 9: Mortality data for women from the study regions near the Dabaoshan mine for which the cancer rates (per 100,000) for 2000-2007 as calculated in the present study. The table showed the mortality data for women, including observed deaths, crude rate, age-adjusted rate and expected deaths, from the study regions near the Dabaoshan mine for which the cancer rates for 2000-2007 as calculated of this study.

\section{Acknowledgements}

The authors thank the Centre for Disease Control and Prevention of Wengyuan County and Guangdong province for providing assistance in collecting samples and conducting the investigations. The authors also thank all the participants for their cooperation in this study. This study was supported by The Ministry of Education 985 Programme of China. 


\section{Author details}

'Department of Preventive Medicine, School of Public Health, Sun Yat-Sen University, Guangzhou, China. ${ }^{2}$ Department of Medical Statistics and Epidemiology, School of Public Health, Sun Yat-Sen University, Guangzhou, China. ${ }^{3}$ The Centre for Disease Control and Prevention of Guangdong province, Guangzhou 510300, China. ${ }^{4}$ The Centre for Disease Control and Prevention of Wengyuan County, Shaoguan 512600, China. ${ }^{5}$ Department of Nutrition, School of Public Health, Sun Yat-Sen University, Guangzhou 510080, China.

\section{Authors' contributions}

MW and WHL contributed to the study design, data analysis, and writing WHL, HS and YY participated in the study design and administered the study. W-QC, CYL, QSH, and ZFR were responsible for the field investigations and data collection. YJX, and AMZ organized the field investigations. All authors read and approved the final manuscript.

\section{Competing interests}

The authors declare that they have no competing interests.

Received: 21 July 2010 Accepted: 16 May 2011 Published: 16 May 2011

\section{References}

1. Zhou JM, Dang Z, Tu YS, Liu CQ: Distrution and characteristics of heavy metals contamination in soils from Dabaoshan mine area. Journal of Agro-Environment Science 2004, 23(6):1172-1176.

2. Wu YG, Lin CX, Tong XL, Lu W, Zhu LX: Environmental impacts of acid mine drainage from Dabaoshan Mine:I.Downstream aquatic ecosystem. Ecology and environment 2005, 14(2):165-168.

3. Lin CX, Lu WZ, Wu YG: Environmental impacts of acid mine drainage from Dabaoshan Mine: II. Agricultural ecosystem. Ecology and Environment 2005, 14(2):169-172.

4. Fu SM, Zhou YZ, Zhao YY, Zeng F, Gao QZ, Peng XZ: Study on heavy metals in soils contaminated by acid mine drainage from Dabaoshan mine, Guangdong. Environmental Science 2007, 28(4):805-812

5. Zeng FG: Chemistry and Cancer in the Environment and Cancer. Beijing: China science and techology press; 2004, 117

6. Cai MF, Dang Z, Wen Z, Zhou JM: Risk assessment of heavy metals contamination of soils around mining area. Ecology and Environment 2004, 13(1):6-8.

7. IARC: Cadmium and cadmium compounds. IARC Monogr Eval Carcinog Risks Hum 1993, 58:119-237.

8. IARC: Lead and lead compounds. IARC Monogr Eval Carcinog Risks Hum 1987, 23:325-415.

9. Agency for Toxic Substances and Disease Registry: Toxicological Profile for Lead. Ga: US department of Health and Human Services, Public Health Service 1999

10. Navarro Silvera SA, Rohan TE: Trace elements and cancer risk: a review of the epidemiologic evidence. Cancer Causes Control 2007, 18(1):7-27.

11. Fu H, Boffetta P: Cancer and occupational exposure to inorganic lead compounds: a meta-analysis of published data. Occup Environ Med 1995, 52(2):73-81.

12. Boffetta P: Epidemiology of environmental and occupational cancer. Oncogene 2004, 23(38):6392-6403.

13. Lalor GC: Review of cadmium transfers from soil to humans and its health effects and Jamaican environment. The Science of the total environment 2008, 400(1-3):162-172.

14. Waalkes MP: Cadmium carcinogenesis. Mutat Res 2003, 533(1-2):107-120.

15. Jarup $L$, Akesson $A$ : Current status of cadmium as an environmental health problem. Toxicol Appl Pharmacol 2009, 238(3):201-208.

16. Hayes RB: The carcinogenicity of metals in humans. Cancer Causes Control 1997, 8(3):371-385.

17. Leone N, Courbon D, Ducimetiere P, Zureik M: Zinc, copper, and magnesium and risks for all-cause, cancer, and cardiovascular mortality. Epidemiology 2006, 17(3):308-314.

18. Gaetke LM, Chow CK: Copper toxicity, oxidative stress, and antioxidant nutrients. Toxicology 2003, 189(1-2):147-163.

19. Obata $H$, Sawada $N$, Isomura H, Mori M: Abnormal accumulation of copper in LEC rat liver induces expression of p53 and nuclear matrixbound p21(waf 1/cip 1). Carcinogenesis 1996, 17(10):2157-2161

20. Barceloux DG: Copper. J Toxicol Clin Toxicol 1999, 37(2):217-230.
21. Pan Y, Loo G: Effect of copper deficiency on oxidative DNA damage in Jurkat T-lymphocytes. Free Radic Biol Med 2000, 28(5):824-830.

22. Marczewska J, Koziorowska JH, Anuszewska EL: Influence of ascorbic acid on cytotoxic activity of copper and iron ions in vitro. Acta Pol Pharm 2000, 57(6):415-418.

23. Powell SR: The antioxidant properties of zinc. J Nutr 2000, 130(5S Suppl):1447S-1454S

24. Bao QS, Lu CY, Song H, Wang M, Ling W, Chen WQ, Deng XQ, Hao YT, Rao S: Behavioural development of school-aged children who live around a multi-metal sulphide mine in Guangdong province, China: a cross-sectional study. BMC Public Health 2009, 9(1):217.

25. Ma WJ, Xu YJ, Zhang YR: The research on death model and diseases burden in the residents of Guangdong Province-the report on the 3rd retrospective study on causes of death in Guangdong Province, 20042005. Guangzhou: Guangdong Economy Press; 2008

26. Ma YH, Zhang XH, Liu ML: A study on the micro-wave digestion method for the measurement of inorganic elements in the whole blood sample. Journal of Northwest University (National Science Edition) 1999, 29(4):317-320.

27. Dai ZC: Method and application of disease surveillance. Beijing: Hua xia press; 1993, 20.

28. Ma WJ, Xu YJ, Zhang YR: The program on the 3rd retrospective study on cause of death in Guangdong province, 2004-2005. In the research on death model and diseases burden in the rsidents of Guangdong province-the report the $3 r d$ rerestrospective study on cause of death in Guangdong province, 2004-2005 Guangzhou: Guangdong Economy Press; 2008, 144

29. Ma WJ, Xu YJ, ZHang YR: The research on death model and diseases burden in the residents of Guangdong province-the report on the 3rd retrospective study on causes of death in Guangdong province, 20042005. Guangzhou: Guangdong economy press 2008, 1-6.

30. Ma WJ, Xu YJ, Zhang YR: Collection, sorting, analysis and elaluation of data. The research on death model and diseases burden in the residents of Guangdong province-the report on the 3rd retrospective study on cause of death in Guangdong province, 2004-2005 GuangZhou: Guangdong Economy Press; 2008, 1-6.

31. Ma WJ, Xu YJ, Zhang YR: The list on the organization of the program on the 3 rd retrospective study on cause of death in Guangdong province, 2004-2005. The research on death model and diseases burden in the residents of Guangdong province-the report on the 3rd retrospective study on cause of death in Guangdong province, 2004-2005 Guangzhou: Guangdong Economy Press; 2008, 141

32. World Health Organization: International Statistical Classification of Diseases AND Related Health Problems. Geneva, Swilzerland: World Health Organization; 101992

33. Kuriyama S, Shimazu T, Ohmori K, Kikuchi N, Nakaya N, Nishino $Y$, Tsubono Y, Tsuji I: Green tea consumption and mortality due to cardiovascular disease, cancer, and all causes in Japan: the Ohsaki study. Jama 2006, 296(10):1255-1265.

34. Abramson JH: WINPEPI (PEPI-for-Windows): computer programs for epidemiologists. Epidemiol Perspect Innov 2004, 1(1):6.

35. Beaumont JJ, Sedman RM, Reynolds SD, Sherman CD, Li LH, Howd RA, Sandy MS, Zeise L, Alexeeff GV: Cancer mortality in a Chinese population exposed to hexavalent chromium in drinking water. Epidemiology (Cambridge, Mass 2008, 19(1):12-23.

36. Schaefer RL: Alternative estimators in logistic regression when the data are collinear. J Statist Comp Sim 1986, 25:75-91.

37. Occupatiol Safety and Health Administration DoL: Occupational safety and health standards: toxic and hazardous substances: cadmium Code of Federal Regulations. 2003, 29:135-229, CFR 1910.1027

38. Jarup L, Elinder CG, Spang G: Cumulative blood-cadmium and tubular proteinuria: a dose-response relationship. Int Arch Occup Environ Health 1988, 60:223-229.

39. Steenland K, Boffetta P: Lead and cancer in humans: where are we now? Am J Ind Med 2000, 38(3):295-299.

40. Nawrot T, Plusquin M, Hogervorst J, Roels HA, Celis H, Thijs L, Vangronsveld J, Van Hecke E, Staessen JA: Environmental exposure to cadmium and risk of cancer: a prospective population-based study. Lancet Oncol 2006, 7(2):119-126.

41. Nakagawa H, Kawano S, Okumura Y, Fujita T, Nishi M: Mortality study of inhabitants in a cadmium-polluted area. Bull Environ Contam Toxicol 1987. 38(4):553-560 
42. Nakagawa $H$, Nishi M, Morikawa $Y$ : Increased urinary beta2-microglobulin and mortality rate by cause of death in a cadmium-polluted area. Environ Health Prevent Med 1996, 1:144-148.

43. Nishijo M, Nakagawa H, Morikawa Y, Kuriwaki J, Katsuyuki M, Kido T, Nogawa K: Mortality in a cadmium polluted area in Japan. Biometals 2004, 17(5):535-538.

44. Menke A, Muntner P, Silbergeld EK, Platz EA, Guallar E: Cadmium levels in urine and mortality among U.S. adults. Environ Health Perspect 2009, 117(2):190-196.

45. Schober SE, Mirel LB, Graubard BI, Brody DJ, Flegal KM: Blood lead levels and death from all causes, cardiovascular disease, and cancer: results from the NHANES III mortality study. Environ Health Perspect 2006, 114(10):1538-1541.

46. Kazantzis G, Lam TH, Sullivan KR: Mortality of cadmium-exposed workers. A five-year update. Scand J Work Environ Health 1988, 14(4):220-223.

47. Jemal A, Graubard BI, Devesa SS, Flegal KM: The association of blood lead level and cancer mortality among whites in the United States. Environ Health Perspect 2002, 110(4):325-329.

48. Kneller RW, Guo WD, Hsing AW, Chen JS, Blot WJ, Li JY, Forman D, Fraumeni JF: Risk factors for stomach cancer in sixty-five Chinese counties. Cancer Epidemiol Biomarkers Prev 1992, 1(2):113-118.

49. Su M, Liu M, Tian DP, Li XY, Yang HL, Huang HH, Yan HF, Zou CQ: Epidemiological investigating of the mortality rate of malignant tumors and their diet habitats among residents of Nanao island in south China sea. J Environ Occup Med 2005, 22(4):312-316.

50. Westendorf J, Middleton A: Chemical aspects of the relationship between drinking water qulity and log-term health effects: An overview. J Am water Works Assoc 1979, 71:417-421.

51. Yang CY, Chiu HF, Cheng MF, Tsai SS, Huang CF, Lin MC: Esophageal cancer mortality and total hardness levels in Taiwan's drinking water. Enironmental research 1999, 81(4):302-308.

52. Zhou YL, Shi XS, Tian J: A meta-analysis study on main risk factor for esophageal cancer. Strait J Prev Med 2004, 10(5):1-3.

53. Yao HY, Shi LY: Meta-analysis of the risk factors on lung cancer in Chinese people. Chin J Epidemiol 2003, 24(1):45-48.

54. Waalkes MP: Cadmium carcinogenesis. Mutation research 2003, 533(12):107-120.

55. Waalkes MP, Rehm S: Chronic toxic and carcinogenic effects of cadmium chloride in male DBA/2NCr and NFS/NCr mice: strain-dependent association with tumors of the hematopoietic system, injection site, liver, and lung. Fundam App/ Toxicol 1994, 23(1):21-31.

56. Kanegane H, Nomura K, Miyawaki T, Tosato G: Biological aspects of Epstein-Barr virus (EBV)-infected lymphocytes in chronic active EBV infection and associated malignancies. Critical reviews in oncology/ hematology 2002, 44(3):239-249.

57. Okano M: Haematological associations of Epstein-Barr virus infection. Bailliere's best practice \& research 2000, 13(2):199-214.

58. Li L, Meng FY: Advance in environment risk factor on adult leukemia. $J$ Environ Occup Med 2006, 23(4):349-351.

59. Zhang J, Pu YP, Yin LH, Yuan H, Song YH: Relationship between environmental risk factors, Genetic polymorphism of metablic enzymes and leukemia. J Environ Occup Med 2004, 21(3):186-189.

60. Morgenstern H: Ecological studies in epidemiology: concepts, principles, and methods. Annu Rev Public Health 1995, 16:61-81.

61. Lustberg M, Silbergeld E: Blood lead levels and mortality. Arch Intern Med 2002, 162(21):2443-2449

62. Staessen JA, Buchet JP, Ginucchio G, Lauwerys RR, Lijnen P, Roels $H$, Fagard R: Public health implications of environmental exposure to cadmium and lead: an overview of epidemiological studies in Belgium. Working Groups. J Cardiovasc Risk 1996, 3(1):26-41.

63. Cheng S: Heavy metal pollution in China: origin, pattern and control. Environ Sci Pollut Res Int 2003, 10(3):192-198.

64. Jarup L, Berglund M, Elinder CG, Nordberg G, Vahter M: Health effects of cadmium exposure-a review of the literature and a risk estimate. Scand J Work Environ Health 1998, 24(Suppl 1):1-51.

\section{Pre-publication history}

The pre-publication history for this paper can be accessed here:

http://www.biomedcentral.com/1471-2458/11/319/prepub doi:10.1186/1471-2458-11-319

Cite this article as: Wang et al:: Cancer mortality in a Chinese population surrounding a multi-metal sulphide mine in Guangdong province: an ecologic study. BMC Public Health 2011 11:319.

\section{Submit your next manuscript to BioMed Central and take full advantage of:}

- Convenient online submission

- Thorough peer review

- No space constraints or color figure charges

- Immediate publication on acceptance

- Inclusion in PubMed, CAS, Scopus and Google Scholar

- Research which is freely available for redistribution

Submit your manuscript at www.biomedcentral.com/submit
C) Biomed Central 